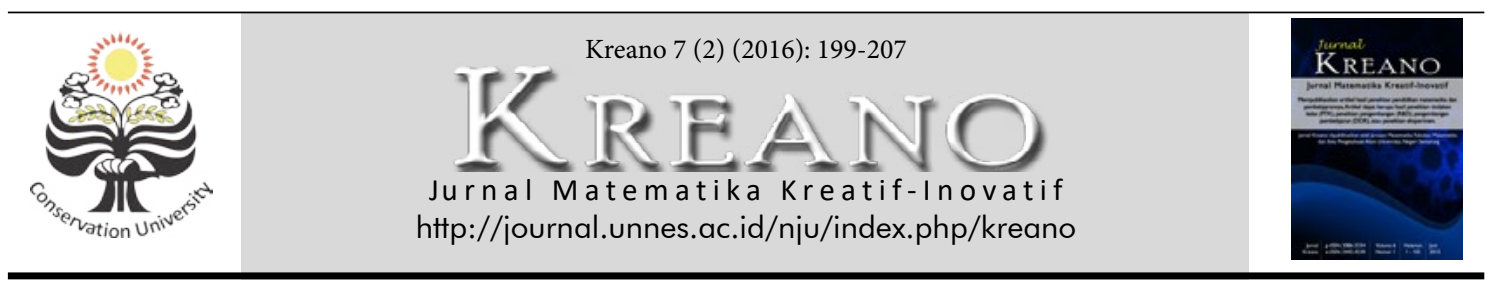

\title{
Pembelajaran Menemukan Nilai PHI melalui Pendekatan Matematika Realistik di Sekolah Dasar
}

\author{
Rahmah Johar ${ }^{1}$, Aklimawati², Cut Morina Zubainur' ${ }^{1}$, M. Ikhsan', \\ dan Adek Elfera Chandrawati ${ }^{3}$ \\ 'Prodi Pendidikan Matematika FKIP Universitas Syiah Kuala \\ ${ }^{2}$ Prodi Pendidikan Matematika FKIP Universitas Serambi Mekkah \\ ${ }^{3}$ MIN Rukoh Banda Aceh \\ Email: rahmahjohar@fkip.unsyiah.ac.id
}

DOI: http://dx.doi.org/10.15294/kreano.v7i2.5996

Received: May, 2016; Accepted: December, 2016; Published: December, 2016

\begin{abstract}
Abstrak
Tujuan penelitian ini adalah untuk mengetahui dampak implementasi Hypothetical Learning Trajectory (HLT) dalam mengajarkan nilai melalui pendekatan matematika realistik. Penelitian ini mendeskripsikan implementasi Hypothetical Learning Trajectory (HLT) melalui penelitian Design Research yang terdiri atas tiga tahap yaitu (i) preparing for the experiment, (ii) the teaching experiment, dan (iii) the retrospective analysis. Penelitian ini melibatkan satu orang guru dan 28 siswa kelas V MIN Rukoh, Banda Aceh. Data dikumpulkan melalui lembar observasi, video pembelajaran, dan catatan lapangan. Hasil penelitian menunjukkan bahwa HLT yang dikembangkan dapat membantu siswa melukis titik pusat dan diameter benda berbentuk lingkaran, menemukan nilai yang paling akurat hasil pembagian keliling dengan diameter lingkaran yaitu Kendala dalam penelitian ini adalah siswa kesulitan melakukan operasi pembagian bilangan desimal.
\end{abstract}

\begin{abstract}
The purpose of this study was to determine the impact of the implementation Hypothetical Learning Trajectory (HLT) in teaching the value of $\pi$ through realistic mathematics approach. This study describes the implementation Hypothetical Learning Trajectory (HLT) through research Design Research, which consists of three stages: (i) preparing for the experiment, (ii) the teaching experiment, and (iii) the retrospective analysis. The study involved one teacher and 28 students of class V MIN Rukoh, Banda Aceh. Data were collected through observation sheets, instructional videos, and field notes. The results showed that the HLT developed to help students paint the center and diameter of a circle-shaped object, find the most accurate value of the division of the circumference to the diameter of the circle is $\pi=3.14$. Constraints in this study were students' difficulty performing division operation decimals.
\end{abstract}

Keywords: realistic mathematics education; hypothetical learning trajectory ( $h l t)$; conceptual understanding; value

\section{PENDAHULUAN}

Banyaknya simbol dan rumus yang digunakan dalam pembelajaran matematika menyebabkan sebagian besar siswa beranggapan bahwa matematika merupakan pelajaran yang sulit dan membosankan. Hal ini terjadi karena siswa tidak diberikan kesempatan untuk mengetahui bagaimana proses terjadinya simbol dan nilai yang biasanya menyertai lambang tersebut. Siswa hanya menggunakan simbol dalam bentuk jadi sehingga tidak memahami makna dari simbol tersebut. Salah satu pokok bahasan matematika yang banyak menggunakan simbol yaitu geometri. Geometri menempati posisi khusus dalam kurikulum matematika, karena banyaknya konsep-konsep yang termuat di dalamnya. Dari sudut pandang psikologi, geometri merupakan penyajian abstraksi dari pengalaman visual dan spasial, misalnya bidang, pola, pengukuran dan pemetaan. Sedangkan dari sudut pandang matematik, geometri menyediakan pendekatan-pendekatan untuk pemecahan masalah, misalnya gambar-gambar, diagram, sistem koordinat, vektor, dan transformasi (Burger \& Shaughnessy, 1986). Menurut NCTM (2000), pada 
dasarnya geometri mempunyai peluang yang lebih besar untuk dipahami siswa dibandingkan dengan cabang matematika yang lain karena geometri sudah dikenal oleh siswa sejak mereka belum masuk sekolah seperti garis, bidang dan ruang melalui aktivitas sehari-hari. Namun, banyak penelitian yang menyatakan bahwa geometri merupakan materi yang sulita diajarkan dan dipelajari oleh siswa (Luneta, 2015).

Berdasarkan diskusi dengan guru di MIN Rukoh Banda Aceh, diperoleh informasi bahwa masih banyak siswa kelas $V$ yang mengalami kesulitan memahami rumus-rumus bangun datar. Siswa tidak mampu memaknai simbol-simbol yang digunakan dalam suatu rumus.Salah satu simbol yang tidak dipahami siswa yaitu nilai Siswa tidak memahami mengapa nilai atau. Hal ini terjadi karena pembelajaran selama ini guru langsung menunjukkan contoh penggunaan nilai tanpa memotivasi siswa untuk menemukan nilai terlebih dahulu. Hal ini mengakibatkan siswa menganggap nilai hanya sebagai simbol yang harus dihafal.

Walle (2007) mengungkapkan bahwa dalam pembelajaran matematika perlu pengembangan konseptual dari rumus bukan sekedar memberikan rumus kepada siswa karena ketika siswa mengembangkan rumusrumus, mereka memperoleh pemahaman konseptual tentang hubungan yang ada dan dapat terlibat langsung dalam suatu proses nyata pengerjaan matematika. Hal ini dapat membantu siswa mengerti dari mana terciptanya rumus dan tidak memandang rumus sebagai suatu yang misterius, cenderung mengingatnya, dan semakin yakin bahwa matematika itu masuk akal. Penggunaan rumus begitu saja dari buku tidak memberikan pengembangan hubungan antar rumus tersebut.

Mengajar matematika yang efektif memerlukan pemahaman tentang apa yang siswa ketahui dan perlukan untuk belajar dan kemudian memberikan tantangan dan dukungan agar mereka dapat mempelajari matematika dengan baik (NCTM, 2000). Guru sebaiknya merancang aktivitas yang dimulai dengan konteks dalam kehidupan sehari-hari siswa dan bantuan alat peraga (jika diperlukan), terutama bagi siswa pada jenjang sekolah dasar (Johar, 2013).
Mempelajari matematika membutuhkan mental yang tinggi dan kecerdasan yang memadai. Hal ini sesuai dengan pendapat Hudoyo (2007) yang mengatakan bahwa pembelajaran matematika merupakan kegiatan mental yang tinggi karena matematika berkenaan dengan ide-ide konsep-konsep abstrak yang tersusun secara hirarki dan penalaran deduksi. Oleh karena itu dalam kegiatan pembelajaran, seringkali seorang siswa tidak dapat menyelesaikan soal-soal dengan tuntaskarena ketidakmampuan mereka mengingat atau memahami konsep-konsep dasar yang pernah mereka pelajari sebelumnya. Untuk mengatasi masalah tersebut, guru perlu memilih pendekatan belajar yang sesuai, sehingga dapat memberi pengalaman yang nyata bagi siswa dan pengetahuan matematika diperoleh secara bermakna.Pendekatan matematika realistik merupakan salah satu pendekatan yang memberikan kesempatan kepada siswa dalam mengkonstruksi konsep dan rumus dalam matematika.

Pendekatan matematika realistik (Realistic Mathematics Education/RME) dikembangkan di Belanda oleh Hans Freudenthal mulai tahun 1971 yang memandang "mathematics is a human activity". Freudenthal berkeyakinan bahwa siswa bukanlah sekedar penerima yang pasif terhadap materi matematika yang siap saji, tetapi siswa perlu diberi kesempatan untuk menemukan (reinvent) kembali konsep matematika melalui aktivitas yang mereka alami sendiri. Siswa harus diberi kesempatan untuk membangun pengetahuan dan pemahaman mereka sendiri melalui penggunaan situasi nyata yang bermakna sehingga menjadi sumber belajar.Jadi, dalam hal ini pembelajaran berpusat pada siswa (student center learning) dan guru hanya sebagai fasilitator. Oleh karena itu fokus pendidikan matematika bukan hanya pada hasil, tetapi juga cara memperoleh hasil (Johar, 2006).

Menurut de Lange (1987) terdapat lima karakteristik pendekatan matematika. Pertama, menggunakan masalah nyata di awal pelajaran. Kedua, siswa menggunakan model atau simbol sendiri untuk merepresentasikan masalaha nyata. Ketiga, menggunakan kontribusi siswa sendiri dalam menyelesaikan masalah dan menegosiasikan strategi mereka. 
Keempat, adanya intraksi antara siswa yang difasilitasi oleh guru. Kelima, mengaitkan (intertwinment) topik matematika dengan topik matematika lainnya atau matapelajaran lainnya.

Freudenthal (Gravemeijer \& Eerde, 2009) menjelaskan bahwa siswa diberikan kesempatan untuk membangun dan mengembangkan ide dan pemikiran mereka ketika mengkonstruksikan matematika. Guru dapat memilih aktivitas pembelajaran yang sesuai sebagai dasar untuk merangsang siswa berpikir dan bertindak ketika mengkonstruksikan konsep matematika tersebut.Langkah pembelajaran dikembangkan berdasarkan kajian teoretis yang memperhatikan prinsip dasar dan karakteristik dalam pembelajaran dengan pendekatan matematika realistik. Langkah-langkah pembelajaran dibuat dengan tujuan memudahkan guru dalam proses belajar mengajar agar menjadi pembelajaran yang lebih sistematis dan bermakna sesuai dengan teori yang dianut. Namun demikian langkah tersebut tidak membatasi gerak guru melainkan dapat dikembangkan sesuai kebutuhan dikelas.

Untuk merancang kegiatan pembelajaran di kelas salah satunya memperkenalkan nilai, guru sebaiknya merumuskan dugaan (konjektur) dan mempertimbangkan reaksi siswa untuk setiap proses pembelajaran yang dilaksanakan. Dalam proses aktivitas tersebut guru harus mengantisipasi aktivitas mental apa saja yang muncul dari siswa dengan tetap memperhatikan tujuan pembelajaran. Pre- diksi dan antisipasi yang dilakukan tersebut disebut Hypothetical Learning Trajectory (HLT) (Simon, 2004). HLT merupakan suatu hipotesa atau prediksi bagaimana pemikiran dan pemahaman siswa berkembang dalam aktivitas pembelajaran.

Berdasarkan uraian di atas, rumusan masalah dalam penelitian ini adalah bagaimana implementasi Hypothetical Learning Trajectory $(H L T)$ dalam mengajarkan nilai melalui pendekatan matematika realistik?.

\section{METODE}

Penelitian ini mendeskripsikan implementasi Hypothetical Learning Trajectory (HLT) yang telah dikembangkan oleh Johar, Ikhsan, \& Zubainur (2014), Aklimawati (2014), dan Johar, Ikhsan, \& Zubainur (2015), melalui penelitian Design Research yang terdiri atas tiga tahap yaitu (i) preparing for the experiment, (ii) the teaching experiment, dan (iii) the retrospective analysis (Gravemeijer dan Cobb, 2006). Langkah pembelajaran dikembangkan berdasarkan kajian teoretis yang memperhatikan prinsip dan karakteristik dalam pembelajaran dengan pendekatan matematika realistik. Kegiatan pembelajaran yang dibahas dalam tulisan ini hanya satu pertemuan pada tahap teaching experiment berkaitan dengan mengenalkan nilai berdasarkan pendekatan tematik menurut Kurikulum 2013 (Depdikbud, 2014). Pada Tabel 1 disajikan HLT berkaitan dengan penemuan nilai pi yang memuat tujuan, aktivitas, dan konjektur (dugaan).

Pembelajaran dilaksanakan pada hari

Tabel 1. Hypothetical Learning Trajectory (HLT) untuk Menemukan Nilai

\begin{tabular}{lll}
\hline Tujuan Pembelajaran & \multicolumn{1}{c}{ Aktivitas } & \multicolumn{1}{c}{ Konjektur } \\
\hline - Siswa mampu me- \\
$\begin{array}{l}\text { lukis titik pusat, jari- } \\
\text { jari, dan diameter } \\
\text { benda berbentuk }\end{array}$
\end{tabular}


senin tanggal 2 Maret 2015, di kelas V(B) MIN Rukoh Banda Aceh. Siswa yang terlibat dalam proses pembelajaran ini berjumlah 28 siswa. Guru yang diamati dalam penelitian ini juga terlibat dalam revisi perangkat pembelajaran.

Pengumpulan data penelitian menggunakan catatan lapangan, rekaman video pembelajaran dan lembar observasi keterlaksanaan pembelajaran. Data dianalisis berdasarkan hasil catatan lapangan, rekaman video pembelajaran dan lembar observasi. Dua diantara penulis berperan sebagai observer dalam penelitian ini.

\section{HASIL DAN PEMBAHASAN}

Aktivitas pertama diawali dengan melukis titik pusat, jari-jari, dan diameter benda berbentuk lingkaran. Aktivitas ini bertujuan untuk membantu siswa dalam menemukan unsur-unsur benda berbentuk lingkaran tanpa harus menjiplaknya terlebih dahulu. Di samping itu aktivitas ini juga mengaitkan antara pengetahuan sebelumnya tentang persegi dengan materi yang akan dipelajari. Hal ini sesuai dengan karakteristik dari pendidikan matematika realistik yaitu intertwining atau keterkaitan antara konsep dalam matematika.

Guru memulai aktivitas pembelajaran dengan mengaitkan tema ekosistem pada materi keliling dan luas lingkaran. Upaya yang dilakukan guru adalah dengan bertanyajawab tentang pengertian ekosistem dan salah satu komponen ekosistem alam/biotik yang sudah dipelajari sebelumnya yaitu tumbuhan. Tumbuhan banyak manfaat bagi manusia salah satunya tumbuhan dapat menciptakan udara segar, sehingga manusia tidak merasakan terlalu panas. Ketika malam hari kipas angin dapat membantu kita mengurnagi rasa panas di dalam ruangan.

Guru menampilkan kipas angin dan sepeda mainan di depan kelas, guru meminta siswa mengamati kedua benda tersebut. Guru meminta seorang siswa menunjukkan letak titik pusat dan jari-jari sepeda. Kemudian guru menunjukkan benda berbentuk lingkaran yang belum diketahui titik pusatnya dan meminta siswa menemukan titik pusatnya. Karena siswa kebingungan menentukan titik pusatnya guru menjiplak benda tersebut di papan tulis dan meminta siswa melukiskan titik pusat dan jari-jari. Seorang siswa maju ke depan dan langsung melukiskan titik pusat dan jari-jari menggunakan rol tanpa mengetahui dengan pasti apakah titik pusat yang dilukis sudah tepat. Berikut cuplikan tanggapan guru terhadap siswa tersebut.

\section{Siswa : (melukis beberapa diameter di dalam lingkaran untuk menemukan titik pusat lingkaran, seperti Gambar 1)}

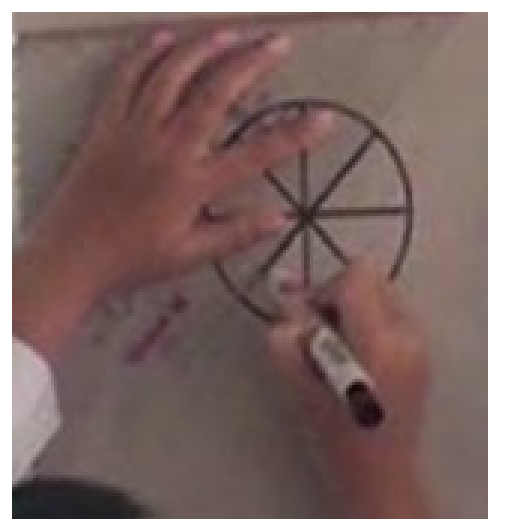

Gambar 1. Siswa menemukan titik pusat lingkaran dengan menggambar garis-garis yang berpotongan di tengah lingkaran

Guru : Sudah tepatkah gambarnya, ada cara lain untuk melukisnya?

Siswa : Sudah tepat bu!

RF : Belum tepat bu, ada cara lain dengan buat petak bu.

Guru : Silahkan RF gambarkan dipapan tulis.

RF : (Siswa melukis persegi didalam lingkaran yang sudah dijiplak gurunya, seperti Gambar 2)

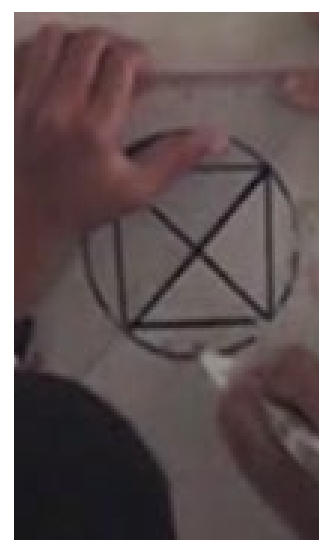

Gambar 2. Siswa menemukan titik pusat lingkaran dengan menggambar-kan persegi terbesar dalam lingkaran 
Dikaitkan dengan konjektur (dugaan) yang dituliskan pada HLT di Tabel 1, ternyata ada siswa yang mampu melukis titik pusat lingkaran dengan cara menggambar persegi terbesar yang titik sudutnya menyinggung lingkaran, lalu menggambar kedua diagonal persegi tersebut sedemikian sehingga perpotongannya merupakan pusat lingkaran.

Guru menanggapi hasil kerja kedua siswa yang mendemostrasikan ke depan kelas dengan cara menegaskan kepada siswa bahwa cara yang pertama belum tentu tepat letak titik pusatnya karena titik pusatnya ditentukan dengan perpotongan garis-garis di dalam lingkaran, cara yang kedua lebih tepat titik pusatnya karena dengan mengambarkan petak atau disebut persegi terbesar yang menyinggung keliling lingkaran, kemudian menghubungkan kedua diagonal persegi sehingga titik potong kedua diangonal persegi merupakan pusat lingkaran. Guru mengingatkan siswa kembali bahwa setiap bangun datar yang sudah dipelajari memiliki keterkaitan seperti halnya ekosistem yang saling berhubungan satu sama lainya, begitu juga bangun datar persegi dengan lingkaran saling berkaitan dalam menemukan titik pusat.

Guru memotivasi siswa untuk mengajukan pendapat tentang diameter. Berdasarkan diskusi yang dilakukan antara guru dan siswa, siswa dapat menyimpulkan pengertian diameter. Kemudian guru menggambarkan kembali lingkaran dan meminta siswa melukiskan diameter lingkaran ke depan kelas. Setelah siswa melukis lingkaran seperti Gambar 1, guru mengajukan pertanyaan, "Yang mana diameter?", lalu siswa menggambar garis vertikal seperti Gambar 3.

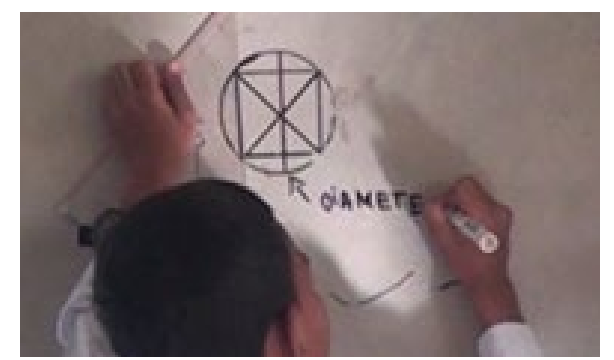

Gambar 3. Siswa melukis titik pusat dan diameter lingkaran

Menurut siswa, diameter pada lingka- ran adalah garis yang vertikal, sedangkan garis yang melalui titik pusat tetapi merupakan diagonal persegi bukan diameter. Menurut siswa garis vertikal lebih panjang dari garis lainnya. Menanggapi hal ini guru meminta siswa membandingkan ukurannya seperti percakapan berikut.

Guru : Apa perbedaan diameter yang temanmu lukis dengan diagonal persegi dalam lingkaran di papan tulis?

Siswa : Diameter lingkaran lebih panjang dari pada panjang garis miring bu

Guru : Tunjukkan tangan yang mau maju ke depan kelas untuk membuktikan bahwa panjang diameter yang lurus (vertikal) lebih panjang dari diameter yang miring. (karena tidak ada siswa yang mau menunjukkan tangan, sehingga guru memanggil IM untuk membuktikan di depan kelas)

IM : (Maju dan mengukurnya), hasil pengukurannya sama bu.

Guru : Sudahkah kalian ketahui semua bahwa panjangnya sama?

Siswa : Sama panjang bu, kelihatan pendek karena miring bu.

Guru : Jadi kesimpulannya keduanya sama panjang dan sama-sama disebut diameter lingkaran.

Siswa dapat melihat bahwa garis yang melalui titik pusat lingkaran pada Gambar 2 adalah sama panjang, sedangkan garis yang melalui titik pusat lingkaran yang didalamnya ada gambar persegi tidak sama panjang (Gambar 3). Berarti persepsi siswa terhadap diameter dipengaruhi oleh gambar persegi yang ada dalam lingkaran. Siswa yang menerima rangsangan dipengaruhi oleh latar dari objek yang mereka lihat merupakan salah satu ciri dari gaya kognitif Field Dependent. Sebaliknya siswa yang dapat mempersepsi objek tanpa dipengaruhi oleh latar dari objek tersebut merupakan ciri dari gaya kognitif Field Independent (Witkin et a1., 1977). Respon siswa yang terjadi di kelas tidak terduga, berbeda dengan konjektur yang ada pada HLT.

Selanjutnya guru mengajukan pertanyaan tentang hubungan diameter dengan jari-jari. Siswa menyebutkan bahwa diameter lingkaran panjangnya dua kali jari-jari. Kemu- 
dian guru meminta siswa mengerjakan LAS nomor 1, yaitu melukiskan titik pusat, jari-jari dan diameter lingkaran langsung pada benda yang berbentuk lingkaran. Sebelum siswa bekerja dalam kelompok, guru meminta salah satu siswa melukiskan titik pusat lingkaran dengan cara melukis persegi terbesar pada benda lingkaran menggunakan penggaris segitiga siku-siku, seperti Gambar 4 .

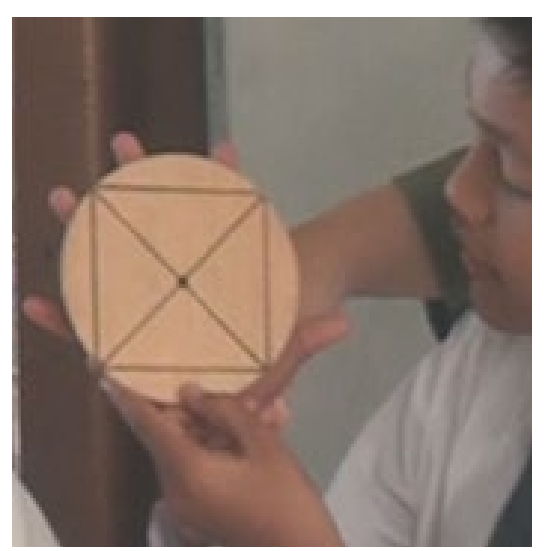

Gambar 4. Siswa melukis titik pusat pada benda berbentuk lingkaran

Selanjutnya siswa bekerja berpasangan dalam kelompok. Dari hasil kerja siswa dapat disimpulkan bahwa semua siswa mampu melukis pusat, jari-jari dan diameter lingkaran dengan bantuan penggaris segitiga siku-siku. Selanjutnya siswa melakukan presentasi. Guru memberikan kesimpulan dengan cara menjelaskan bahwa diameter dan jari-jari pada lingkaran tak berhingga banyaknya, bukan hanya yang dilukiskan saja.

Selanjutnya guru menyajikan beberapa gambar berbentuk lingkaran seperti gambar bundaran di jalan, permukaan kolom renang berbentuk lingkaran, dan kipas angin.Guru meminta siswa mengamati kipas angin yang dihadirkan guru di depan kelas. Guru juga menceritakan kepada siswa: " ada seorang penjahit ingin menjahit tutup kipas angin dengan menambahkan pita, tetapi penjahit tersebut ingin menentukan panjang pita yang dibutuhkan". Bagaimaan membantu penjahit menentukan panjang pita?. berikut cuplikan percakapan guru untuk menemukan nilai.

Guru : Coba kalian perhatikan, bagaimana cara penjahit menemukan panjang pita yang dibutuhkan

\begin{tabular}{|c|c|}
\hline swa & $\begin{array}{l}\text { : Mengukurnya dengan meteran kain } \\
\text { bu. }\end{array}$ \\
\hline Sur & : Adakah cara lain? \\
\hline$R F$ & $\begin{array}{l}\text { Mengukur diameter, lalu kalikan } 2 \\
\text { bu. }\end{array}$ \\
\hline iuru & $\begin{array}{l}\text { : Coba perhatikan manakah yang leb- } \\
\text { ih panjang, diameter atau keliling } \\
\text { kipas angin? }\end{array}$ \\
\hline iswa & : Keliling kipas angin bu \\
\hline uru & $\begin{array}{l}\text { : Berapa kali panjang diameter pan- } \\
\text { jang keliling lingkaran, maukah kita } \\
\text { buktikan sekarang? }\end{array}$ \\
\hline swa & : mau bu \\
\hline uru & $\begin{array}{l}\text { (menunjuk dua orang siswa ke de- } \\
\text { pan kelas untuk mengukur panjang } \\
\text { keliling benda lingkaran kelom- } \\
\text { poknya dan mengukur diameter } \\
\text { benda tersebut, dari hasil pengu- } \\
\text { kuran diperoleh keliling } 28 \mathrm{~cm} \text { dan } \\
\text { diameter } 9 \mathrm{~cm} \text { ) }\end{array}$ \\
\hline iswa & $: 4 b u$. \\
\hline urc & :Coba perhatikan lagi \\
\hline Sisw & $: 3 b u$ \\
\hline Guru & :Tetap 3 nilain \\
\hline Sisw & :Tidak bu, lebih satu. \\
\hline RF & : Berarti hasilnya berkoma bu, 3,1 bu. \\
\hline Guru & : Dari manakah hasilnya 3,1? \\
\hline RF & : Dari 28/9 bu. \\
\hline Gurc & $\begin{array}{l}\text { : Mari kita buktikan sama-sama. ( } \\
\text { guru melakukan pembagian bersusun } \\
\text { di papan tulis dan hasil baginya ber } \\
\text { nilai } 3,11 \text {, sepertiGambar 5) }\end{array}$ \\
\hline
\end{tabular}

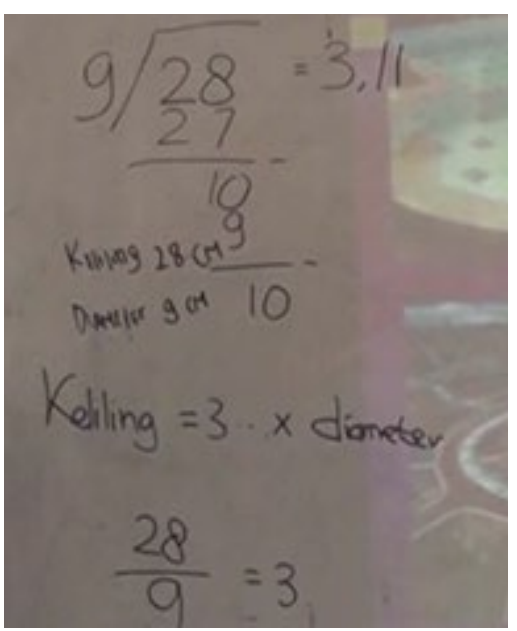

Gambar 5: Guru bersama siswa membagi panjang keliling dengan diameter lingkaran 


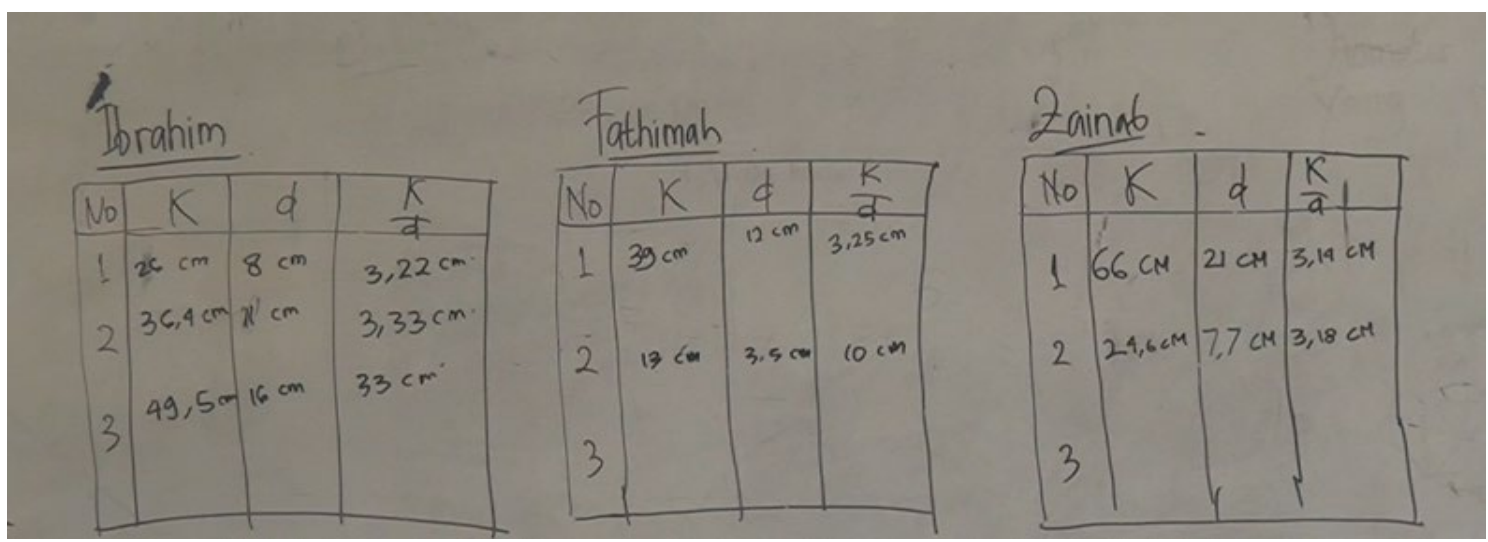

Gambar 6: Tabel hasil perbandingan panjang keliling dan diameter lingkaran

Setelah menemukan nilai perbandingan panjang keliling dengan diameter, guru meminta siswa kembali mengerjakan LAS nomor 2, yaitu menghitung hasil perbandingan panjang keliling dan diameter benda berbentuk lingkaran secara berpasangan dalam kelompok. Setelah semua kelompok menemukan nilai perbandingan keliling dan diameter, guru meminta semua kelompok menuliskannya di papan tulis. Gambar 6 adalah hasil kerja tiga kelompok siswa dari 5 kelompok siswa dalam menemukan nilai.

Berikut cuplikan percakapan yang dilakukan guru untuk menyimpulkan nilai .

Guru : Coba perhatikan setiap hasil perbandingan.(guru meminta siswa menyebutkan satu persatu hasil perbandingan tersebut)

Siswa : (dengan serempak menbacakan hasil perbandingan)

Guru : Coba sebutkan bilangan mana yang paling berbeda dari semua yang ada

Siswa : 10 bu

Guru :(melingkaribilangan 10)

Siswa : 33 bu

Guru : (melingkaribilangan 33)

Siswa : 10 bu

Guru :(melingkaribilangan 10)

Guru : Apa yang menyebabkan bilangan tersebut berbeda?

Siswa : Karena hasilnya terlalu banyak bu

Guru : Jadiberapa juga harusnya

Siswa : 3 bu

Guru : (menuliskan 3 di papan tulis), coba sekarang kalian perhatikan komanya, angka berapa yang paling sering muncul?

Siswa : 3,11 bu

Guru : lya kalian benar, ada yang bilangan apa 3,11 itu, dan dari hasil apa diperolehnya?

Siswa : Hasil perbandingan keliling dan diameter bu.

Guru : kalian tahu tidak apa itu namanya?, namanya adalah pi lambangnya adalah yang diperoleh dari hasil perbandingan keliling dengan diameter. (Guru memberikan penguatan bahwa nilai diperoleh masih kurang tepat disebabkan pengukuran yang kurang teliti sehingga masih ada nilai sama dengan seperti hasil pengukuran yang terdapat pada papan tulis, sedangkan nilai $=3,11$ sudah mendekati nilai yang benar, tetapi sesuai kesepakatan nilai yang benar adalah 3,14 seperti yang diperoleh kelompok Zainab).Berikan tepuk tangan untuk kelompok Zain$a b$

Siswa : (tepuk tangan)

Guru : kesimpulannya kelompok Zainab sudah sangat teliti dalam menemukan nilai jadi nilai yang benar adalah?

Siswa : 3,14 bu.

Untuk mengakhiri pembelajaran, guru menanyakan hal baru yang diperoleh siswa saat belajar, dan guru bersama siswa menyimpulkan hasil pembelajaran. Kemudian guru memberikan penilaian terhadap cara siswa mengemukakan pendapat dalam bekerja sama. Guru memilih kelompok yang diberikan nilai tertinggi, yaitu kelompok Abdullah dan 
kelompok Zainab.

Setelah mengimplementasikan desain pembelajaran yang telah dirancang, peneliti dan guru melakukan refleksi. Secara umum proses belajar mengajar berlangsung dengan baik. Siswa secara aktif terlibat dalam kegiatan pembelajaran dan menemukan konsep nilai secara bermakna. Hal ini sesuai dengan pendapat Widjaja et al (2010) bahwa penggunaan konteks yang bermakna maupun alat peraga dapat membantu siswa menkonstruksi konsep matematika dan menyelesaikan masalah, serta aktivitas siswa selama mengikuti proses pembelajaran dengan menggunakan pendekatan realistik mengalami peningkatan (Anugrahana, 2015).

Belajar matematika yang telah dilakukan sesuai dengan idasar pendekatan matematika realistik yaitu "mathematics is a human activity", dan juga sesuai dengan pandnagan Bruner yaitu belajar mengenai konsep-konsep dan struktur-struktur matematika yang terdapat dalam materi yang dipelajari, serta mencari hubungan antara konsep-konsep dan struktur-struktur matematika itu (Ratumanan, 2004). Siswa terlibat aktif dalam aktivitas pembelajaran sehingga melalui aktivitas pembelajaran tersebut siswa menemukan sendiri konsep dan struktur yang tercakup dalam materi yang sedang dibahas, hal ini akan lebih mudah dipahami dan diingat siswa.

Implementeasi HLT untuk mengenalkan nilai di atas mengalami kendala pada kegiatan mencari hasil pembagian keliling terhadap diameter. Terdapat siswa yang mengalami kesulitan membagi dikarenakan panjang keliling dan diameter yang diukur siswa berupa bilangan desimal. Untuk mengatasi masalah tersebut, pada saat pembelajaran guru membantu siswa melakukan pembagian bilangan desimal. Sebaiknya siswa kelas V Sekolah Dasar telah lancar melakukan pembagian dengan bilangan desimal sebelum mempelajari nilai - Oleh karena itu, untuk mengajarkan matematika harus diperhatikan kehirarkian konsep matematika (Hudoyo, 2007).

\section{PENUTUP}

\section{Simpulan}

Implementasi Hypothetical Learning Trajectory
(HLT) dalam mengajarkan nilai melalui pendekatan matematika realistik meliputi aktivitas melukis titik pusat dan diameter benda berbentuk lingkaran dengan bantuan rol segitiga dan mengukur panjang keliling benda berbentuk lingkaran, serta menentukan nilai perbandingan keliling dengan diameternya. Akhir kegiatan siswa dan guru menyimpulkan berdasarkan kesepakatan bersama bahwa nilai

Pembelajaran yang dilaksanakan dengan pendekatan matematika realistik dapat memberikan kesempatan kepada siswa dalam mengembangkan pola pikirnya. Pembelajaran menemukan nilai yang biasanya hanya langsung diberikan guru kepada siswa sebenarnya berasal dari fenomena yang terjadi di dunia nyata dan dapat dipelajari bagaimana cara menemukannya, sehingga siswa mampu menemukan nilai secara nyata dan mampu memahami makna nilai yang sebenarnya.

\section{DAFTAR REFERENSI}

Aklimawati (2014). Local Instruction Theory (LIT) untuk Mengembangkan Pemahaman Siswa pada Materi Luas dan Keliling Menggunakan Konteks Rapa'i di Sekolah Dasar. Tesis PPs Universitas Syiah Kuala (tidak diterbitkan).

Anugrahana, A. (2015). Pengaruh pembelajaran matematika dengan menggunakan pendekatan realistik terhadap aktivitas siswa dan hasil belajar siswa di sekolah dasar. Didaktika Jurnal Ilmu Pembelajaran Ke-SD-an, 3(2).

Burger, W. F \& Shaughnessy, J. M. (1986). Characterizing the van Hiele Levels of Development in Geometry. Journal for Research in Mathematics Education, 17(1), 31-48.

de Lange, J. (1987). Mathematics, insight, and meaning. The Netherlands, Utrecht: OW\& OC.

Depdikbud (2014). Permendikbud No. 57 Tahun 2014. Jakarta: Depdikbud

Gravemeijer, K.\&Cobb, P. (2006). Design Research from a Learning Design Perspective. In Jan van den Akker etal. (Edts) Educational Design Research. London: Routledge.

Gravemeijer, K. \& Van Eerde, D. (2009). Design Research as a Means for Building a Knowledge Base for Teachers and Teaching in Mathematics Education. The Elementary School Journal, 109(5), 510524 .

Hudoyo, H. (2007). Strategi Belajar dan Mengajar Matematika. Malang: IKIP Malang.

Johar, R. (2006) Pendidikan Matematika Realistik: Pendekatan Baru dalam Pembelajaran Matematika. Jurnal Wacana FKIP Unsyiah, 5(1).

Johar, R. (2013). Alat Peraga Matematika. Makalah disampaikan pada Seminar Alat Peraga di STAIN 
Malikussaleh, tanggal 23 September 2013.

Johar, R., Ikhsan, M., dan Zubainur, C. M. (2014). Tingkat Kepedulian (Stages of Concern) Guru Memanfaatkan Video dalam Melaksanakan Pembelajaran Matematika dengan Pendekatan Realistik untuk Mengembangkan Karakter Siswa. Laporan Penelitian Hikom. Universitas Syiah Kuala (Tidak diterbitkan).

Johar, R. (2015). Tingkat Kepedulian (Stages of Concern) Guru Memanfaatkan Video dalam Melaksanakan Pembelajaran Matematika dengan Pendekatan Realistik untuk Mengembangkan Karakter Siswa. Laporan Penelitian Hikom. Universitas Syiah Kuala (Tidak diterbitkan)

Luneta, K. (2015). Understanding students' misconceptions: An analysis of final Grade 12 examination questions in geometry. Pythagoras, 36(1), 11 pages.

NCTM (2000). Principles and Standar for School Math- ematics. USA: NCTM

Ratumanan, T.G. (2004). Belajar dan Pembelajaran. Surabaya:Unesa University Press.

Simon, M. (2004). Explicating the Role of Mathematical Tasks in Conceptial Learning: An Elaboration of the Hypothetical Learning Trajectory. Penn State University

Walle, J.A. (2007). Matematika Sekolah Dasar dan Menengah Pengembangan Pengajaran. Jilid 2. Jakarta: Erlangga.

Widjaja, W., Dolk, M., \&Fauzan, A. (2010).The Role of Contexts and Teacher's Questioning to Enhance Students' Thinking. Education Journal in Southeast Asia. 33(2), 168-186.

Witkin, H. A., Moore, C. A., Goodenough, D. R., \& Cox, P. W. (1975). Field-dependent and field-independent cognitive styles and their educational implications. ETS Research Bulletin Series, 1975(2), 1-64 